\title{
Native Hawaiian
}

National Cancer Institute

\section{Source}

National Cancer Institute. Native Hawailian. NCI Thesaurus. Code C43394.

A person having origins in any of the original peoples of Hawaii. 